\title{
Assessment of Information and Communications Technology Skills Possessed by Teachers in Technical Colleges of Kano State, Nigeria
}

\author{
Mujittapha Idris Wawo', Dauda Moses ${ }^{2 *}$, Nasiru Bello Mohammed ${ }^{3}$, Rabiu Falama \\ Akila $^{2}$ \\ ${ }^{I}$ Department of Electrical Engineering, School of Technology, Kano State Polytechnic, Nigeria \\ ${ }^{2}$ Department of Electrical Technology Education, Modibbo Adama University of Technology, Yola \\ Adamawa State, Nigeria \\ ${ }^{3}$ School of Education, Federal College of Education (Technical), PMB 60 Gombe, Gombe State, \\ Nigeria
}

\begin{tabular}{|c|c|}
\hline \multirow[t]{2}{*}{ Article Info } & \multirow{16}{*}{$\begin{array}{l}\text { Abstract } \\
\text { Purpose: The main purpose of this study is to assess of information and } \\
\text { communications technology skills possessed by technical teachers in } \\
\text { technical colleges of Kano State, Nigeria. } \\
\text { Approach/Methodology/Design: A descriptive survey research design was } \\
\text { adopted for the study. The population of the study was } 157 \text { which consisted } \\
\text { of } 86 \text { experienced and } 71 \text { inexperienced technical teachers of Technical } \\
\text { Colleges in Kano State. The instrument used for data collection was a } \\
\text { structured questionnaire titled: Assessment of Information and } \\
\text { Communications Technology Skills Possession Question (AICTSPQ) } \\
\text { developed by the researchers. The instrument was validated by three experts } \\
\text { and a reliability coefficient of O.78 was obtained using Cronbach Alpha } \\
\text { reliability method. Mean and standard deviation was used to answer the } \\
\text { research questions while z-test was used to test the null hypotheses at } 0.05 \\
\text { level of significance. } \\
\text { Findings: The finding of the study revealed that Technical teachers are } \\
\text { unskillful in ICT operation such as MS excel, Photoshop, database, } \\
\text { animation, forum and Corel draw; and have a low level of ICT utilization. } \\
\text { Practical Implications: The findings of the study have implications for } \\
\text { concerned authorities. The Government should provide ICT infrastructure in } \\
\text { the State's Technical Colleges in order to have conducive environment for } \\
\text { teaching of the trade subjects and enforce integration by regular supervision } \\
\text { among others. } \\
\text { Originality/value: The technical teachers were unskilful in the following; MS } \\
\text { excel, Photoshop, database, animation, forum and Corel draw, video } \\
\text { conferencing, instructional game, interactive whiteboard and online teaching } \\
\text { as the utilization of ICT facilities was low among technical teachers in } \\
\text { Technical Colleges of Kano State. }\end{array}$} \\
\hline & \\
\hline $\begin{array}{l}\text { Article history: } \\
\text { Received: } 26 \text { May } 2021\end{array}$ & \\
\hline Revised: 21 July 2021 & \\
\hline Accepted: 22 July 2021 & \\
\hline Keywords: & \\
\hline $\begin{array}{l}\text { Assessment, } \\
\text { ICT, }\end{array}$ & \\
\hline Skills, & \\
\hline Technical Teacher, & \\
\hline Technical Colleges & \\
\hline Paper Type : & \\
\hline & \\
\hline Research Article & \\
\hline Corresponding Author: & \\
\hline Dauda Moses & \\
\hline $\begin{array}{l}\text { Email: } \\
\text { mulkidon1@ gmail.com; } \\
\text { mulkidon1@ mautech.edu.ng }\end{array}$ & \\
\hline
\end{tabular}

\section{Introduction}

Technical colleges are established purposely to produce craftsmen in various disciplines. According to Okoye and Okwelle (2017), the main purpose of technical colleges in Nigeria is to kindle technological and industrial development by developing and utilizing technologies for industrial and economic advancement. Technical college is an integral part of the total educational system. It contributes towards the development of good citizenship 
by developing the physical, social, civic, cultural and economic competencies of the individual (Saidu \& Ajuji, 2017). In technical colleges, students are trained to acquire relevant knowledge and skills in different occupations for employment in the world of work (National Board for Technical Education [NBTE], 2007). They give full vocational training intended to prepare students for entry into various occupations. The available programs in Technical Colleges according to (NBTE 2007) are; Automobile trade, Building and woodwork trades, Business trades, Computer trades, Electrical and Electronic trades, Hospitality trades, Mechanical trades, Printing trades, Textile trades and General education. The fact that ICT has moved into the society so rapidly, the need thus arises for everyone to quickly acquire basic ICT skills in order to pursue ones career goals and function effectively in the society with the required skills.

Skills are more commonly used in the context of trade, occupation and vocation and are usually aimed at practical purpose (Kumazhege \& Egunsola, 2014). Skill is thought of as a quality of performance which does not depend solely upon a person's fundamental, innate capacities but must be developed through training, practice and experience. Although skills depend essentially on learning, it also includes the concept of efficiency and economy in performance. Skills, in general, should be understood as being something that can be learnt and improved with practice. ICT skills also known as digital competency involve confident and critical use of information and communication (ICT) in the general population and provide the necessary context (knowledge, skills and attitudes) for working living and learning in a society (UNESCO, 2015). According to Rastogi and Malhotra (2013) ICT skill is the ability or competence needed to use efficiently the elementary functions of ICT to retrieve access, store, produce, presents and exchange information and to communicate and participate in a collaborative networks via internet. Rastogi and Malhotra added that technical Teachers' ICT skills needed include their ability to use the wide variety of technologyrelated tools and their application to classroom teaching, in particular, and to the totality of teaching-learning process in general.

Knowledge and Skill of ICT is necessary for effective teaching and learning. The major challenge to teacher education in Nigeria is that of insufficient knowledge and skills in teaching using ICT (Rastogi \& Malhotra, 2013). ICT skill is a necessity for all teachers to guarantee relevance of the system and its products in the $21^{\text {st }}$ century. Many schools in Nigeria still operate the traditional education system with little or no adaptation to ICT. To benefit from the ubiquity of nformation and to facilitate communication among professional networks, school teachers need, not only to be trained and re-trained in ICTs, but also facilities must be provided by government to enable teacher and their students access to these remain uninterrupted, more so that the world is gradually becoming a global village. For our future teachers to be able to operate effectively and efficiently they must imbibe the new technologies and methodologies of the modern times (Mohammed \& Yarinchi, 2013). In today's rapid technological changes, it is imperative to undertake ICT skills assessment to encourage a consultative approach towards identifying workforce skills and key areas of learning and development. 
The skills to use computer according to Akintunde (2014) is not the only ICT skill required to make valuable use of information stored in the internet. In order to make adequate use of these online resources, literacy in ICT or information is needed. Nikitakis (2017) referred to ICT skill as the ability to totally comprehend and acquire a whole lot of capacities, which include recognizing, spotting, evaluating information as well as making effective use of it. This may imply that alongside these fundamental skills, the abilities to inquire, communicate and collect information are essential. Using computers effectively is now a crucial part of every student's education. Haywood (2013) mentioned some core ICT skills which include knowledge of: spreadsheet, word processors, database and presentation. These ICT skills are essential in our present world in order to enable one have access and utilize information. These ICT skills are required in these contemporary times to enable students function effectively. UNESCO (2017) reiterated that ICT leads to general access to education, equity in education, transfer of quality learning and teaching, teachers 'professional growth and efficient educative management, governance and administration. This thus implies that teachers can improve their teaching method/strategies through proper and quality usage of ICT. As a result, universities, government and employers are expected to pay attention to teachers' ICT skills, because these are the people to restructure future for the students/learners (Basil, 2020).

In a study carried out by Siddiquah and Salim (2017), they noted that majority of the teachers have access to computers and internet facilities both at home and in the universities, as such, they possess some skills such as knowledge of Microsoft word, Microsoft PowerPoint, searching and browsing on the internet, social networking, e-mail, uploading file, and video games. Conversely, amidst these various skills possessed by some teachers, it is obvious that they lack other skills such as proper usage of e-library, discussion forums and blogging. Olurinola (2016) stated that PowerPoint should be used in teaching and learning as it facilitates learning among student. In a study by (Odede \& Enakerakpo, 2014), the researchers stated that if teacher possess adequate ICT skills, they can efficiently make use of the internet and other online teaching application.

Odede and Enakerakpo (2014) further added however that the ICT skills acquired by some teachers were acquired through conscious effort made by teachers themselves through handbooks and manuals, friends and courses in their various institutions. Consequently, (Siddiquah \& Salim, 2017) noted that the teachers engage themselves in doing other computer related activities instead of waiting for government funded programs. This is because, most of the teachers believed that using ICT ease their research work and teaching pedagogy. Perhaps this is because everything is now at their fingertips courtesy of ICT.

Studies have however revealed that teachers face series of challenges in acquiring and utilizing these skills. (Anyim, 2018) stated that some of the challenges of acquiring ICT skills include; lack of funding, failure of the curriculum to include ICT, poor attitudes toward acquiring ICT skills, unavailability of training opportunities, poor ICT facilities, high cost of ICT literacy training and lack of interest in digital information. Adeosun (2010) conducted a study describing the situation of ICT which was very particular about the state of things in 
Nigeria, as a great challenge to effective learning, the researcher mentioned poor infrastructure as one of the major issue affecting the full implementation of ICT; very good internet access, proper and adequate hardware among other infrastructures are necessary for basic and advanced level of ICT enabled instructions. It is clear that in terms of computer access and usage, developed, developing and underdeveloped countries are not comparable; the difference is amazing as there are fewer computers and the usage in underdeveloped countries compared to develop and developing countries.

Duhu, Mbaga, Quahha and Danzaria (2014) in their study on the Perception of electrical engineering trade teachers on the use of information and Communication Technology for teaching in Technical Colleges in Adamawa and Gombe States of Nigeria reported that electrical engineering teachers perceived themselves as having inadequate skills required to use the ICT for classroom instructions, furthermore, the teachers were not comfortable with regards to the role of ICT in classroom management/control and loyalty from students. In another study conducted by Sango and Aliyu (2018) on challenges militating against the utilization of ICT by Nigerian teachers suggested that lack of skills, interests, time, inadequate training, lack of appreciation of the benefits of ICT use and the tasking nature of the preparation of ICT utilization are the major challenges militating against the utilization of ICT by teachers.

Considering the constraints to effective ICT utilization, Deebom, and Goma, (2018) conducted a study on utilization of ICT for sustainable manpower development among technical educators in tertiary institutions in Rivers State, Nigeria; the study discovered that despite the benefits of ICT, its utilization by technical educators is constrain by lack of inservice training on the use of ICT, inadequate ICT facilities, poor supervision and administration of ICT programmes, high cost of acquisition of ICT facilities, low internet frequency etc.

It cannot be overemphasized that the successful integration of ICT into the school depends on teacher being aware of the relevance of ICT as a means of providing access to a richer range of resources for themselves and the students (Deebom \& Goma 2018). They must also be convinced of the comparative effectiveness of ICT facilities in the classroom over the traditional method of teaching (Etuk, 2016). Teachers use ICT to display information, create charts, monitor students and engage students. Students use ICT for learning, practicing and expanding what they have learned. In order to produce students that could be responsive to the competitive world of work, teachers must be well trained on how to use various ICT facilities. According to Sango and Aliyu (2018) basic ICT skills such as laptop operating, elearning, smart classrooms, didactic equipment and stimulations are the keys to education today.

Information and Communication Technology (ICT) skill is imperative to human daily activities. How much skills of ICT an individual has, is fast becoming a determining factor to securing a proper job and good pay in Nigeria, ICT skills are most required and requested for, in any kind of employment. There is hardly any modern organization that operates without the use of ICT. The ICT skills as well as the internet is a necessity for all teachers to 
guarantee the relevance of the system and its products in the $21^{\text {st }}$ century. To benefit from the ubiquity of information and to facilitate communication among professional networks, school teachers need, not only be trained and re-trained in ICTs, but facilities must also be provided by government to enable teacher and their students access to these remain uninterrupted, more so that the world is gradually becoming a global village. For our future teachers to be able to operate effectively and efficiently, they must imbibe the new technologies and methodologies of the modern times. From the observation of the researchers, the technical teachers have reservation for the use of ICT facilities in Government Technical Colleges in Kano State. It is against this backdrop that the study was undertaken.

The main purpose of this study is to assess information and communications technology skills possessed by technical teacher in technical colleges of Kano State, Nigeria. Specifically, the study answered the following research questions:

1. What are the ICT Skills possessed by technical teacher in Technical Colleges of Kano State?

2. What is the level of ICT utilization by technical teacher in Technical Colleges of Kano State?

The study also tested the following null hypotheses at 0.05 level of significance:

1. There is no significance difference between the mean responses of technical experienced teachers and inexperienced teachers on the ICT skills possessed by technical teacher in Technical Colleges of Kano State.

2. There is no significance difference between the mean responses of technical experienced teachers and inexperienced teachers on the level of ICT utilization by technical teacher in Technical Colleges of Kano State

\section{Methodology and Procedures}

The study adopted a descriptive survey research design and was conducted in Kano State, Nigeria. Kano State borders Katsina State to the north-west, Jigawa State north-east, Bauchi State to the south-east and Kaduna State to the south-west. The population of the study was 157 which consisted of 86 experienced and 71 inexperienced technical teachers of Technical Colleges in Kano State. No sampling technique was employed as the entire population was used. The instrument used for data collection was a structured questionnaire titled: Assessment of Information and Communications Technology Skills Possession Question (AICTSPQ) developed by the researchers. The responses on the questionnaire were structured on a 5-point Rating scale of: Highly Utilized (HU)/ Highly Skillful (HS) = 5, Utilized (U)/ Skillful (S) = 4, Moderately Utilized (MU)/ Fairly Skillful (FS) = 3, Slightly Utilized (SU)/ Unskillful (U) $=2$, Not Utilized (NU)/ Highly Unskillful (HU) $=1$. The questionnaire was validated by three experts from the Department of Electrical Technology Education, Modibbo Adama University of Technology Yola, Adamawa State. The reliability of the instrument was obtained by administering the questionnaire to 8 technical teachers from Government Technical College Ringim and Government Technical College Hadejia, 
both in Jigawa State. The reliability coefficient of the instrument was found to be 0.78 . Data for the study was collected by the researchers with help of two research assistants. Mean statistic was used to answer the research questions of the study while z-test was used to test the null hypotheses at 0.05 level of significance. Any item with the mean above 3.49 was considered Skillful/Utilize while those with means below 3.50 were considered Unskillful/not utilized. The hypotheses was that, when Z-calculated value is greater than Z-critical value, the null hypothesis was rejected and if otherwise was accepted

\section{Results and Discussion}

\section{ICT Skills Possessed by Technical Teachers in Technical Colleges of Kano State}

Table 1: Mean Rating and Standard Deviation of Opinion of the Respondents on ICT Skills possessed

\begin{tabular}{|c|c|c|c|c|c|c|c|c|}
\hline \multirow[b]{2}{*}{$\mathbf{S} / \mathbf{N}$} & \multirow[b]{2}{*}{ Items } & \multicolumn{2}{|c|}{$\mathrm{N}_{1}=86$} & \multicolumn{2}{|c|}{$\mathbf{N}_{2}=71$} & \multicolumn{3}{|c|}{$N=157$} \\
\hline & & \multicolumn{2}{|c|}{$\bar{X}_{1} \sigma_{1}$} & \multicolumn{2}{|c|}{$\bar{X}_{2} \sigma_{2}$} & \multirow{2}{*}{$\frac{\overline{\boldsymbol{X}}_{\mathbf{G}}}{3.72}$} & \multirow{2}{*}{$\begin{array}{l}\boldsymbol{\sigma}_{\boldsymbol{G}} \\
1.05\end{array}$} & \multirow{2}{*}{$\begin{array}{l}\text { Remarks } \\
\text { Skillful }\end{array}$} \\
\hline 1. & Word Processor (MS Word) & 3.17 & 1.16 & 4.19 & 0.96 & & & \\
\hline 2. & Presentation Programs (Power Point) & 3.19 & 1.21 & 3.90 & 0.86 & 3.58 & 1.02 & Skillful \\
\hline 3. & Spreadsheets (Excel) & 3.62 & 0.88 & 3.84 & 1.22 & 3.74 & 1.06 & Skillful \\
\hline 4. & Networking (Internet browsing) & 3.88 & 1.40 & 4.19 & 1.03 & 4.05 & 1.20 & Skillful \\
\hline 5. & Operating Systems (Windows) & 3.62 & 1.08 & 3.77 & 0.91 & 3.70 & 0.99 & Skillful \\
\hline 6. & Receiving/sending e-mail & 4.00 & 0.92 & 3.65 & 1.47 & 3.81 & 1.22 & Skillful \\
\hline 7. & Image Editing (Photoshop) & 2.92 & 0.92 & 2.61 & 1.16 & 2.75 & 1.05 & Unskillful \\
\hline 8. & Databases (Access) & 2.85 & 1.17 & 3.00 & 1.30 & 2.93 & 1.24 & Unskillful \\
\hline 9. & Animation Programs (Flash) & 2.38 & 1.00 & 2.74 & 1.19 & 2.58 & 1.10 & Unskillful \\
\hline 10. & Forum & 2.81 & 0.96 & 2.81 & 1.12 & 2.81 & 1.05 & Unskillful \\
\hline 11. & Desktop Publishing (Corel Draw) & 2.31 & 1.00 & 3.16 & 1.17 & 2.77 & 1.09 & Unskillful \\
\hline 12. & Chat and social network & 3.54 & 1.60 & 4.06 & 1.11 & 3.82 & 1.33 & Skillful \\
\hline 13. & Video Conference Programs & 3.35 & 1.33 & 3.06 & 1.22 & 3.19 & 1.27 & Unskillful \\
\hline 14. & Instructional Game & 3.50 & 1.05 & 2.81 & 1.35 & 3.12 & 1.21 & Unskillful \\
\hline 15. & Interactive whiteboard & 2.88 & 1.28 & 2.94 & 1.44 & 2.91 & 1.37 & Unskillful \\
\hline 16. & online teaching & 3.73 & 0.94 & 3.35 & 1.28 & 2.20 & 1.12 & Unskillful \\
\hline 17. & online information searching & 3.42 & 1.52 & 3.81 & 1.26 & 3.63 & 1.38 & Skillful \\
\hline 18. & Projection system & 3.81 & 1.00 & 3.29 & 1.27 & 3.53 & 1.15 & Skillful \\
\hline \multirow[t]{2}{*}{19.} & Mobile smartphones & 4.00 & 1.18 & 4.03 & 1.26 & 4.02 & 1.22 & Skillful \\
\hline & Grand Mean & & & & & 3.35 & 1.16 & Unskillful \\
\hline
\end{tabular}

Key: $\overline{\boldsymbol{X}}_{1}=$ mean response of technical experienced teachers, $\overline{\boldsymbol{X}}_{\mathbf{2}}=$ mean response of technical inexperienced teachers $\bar{X}_{\mathrm{G}}=$ Grand of items, $\sigma=$ standard deviation, $\mathrm{N}_{1}=$ number of technical experienced teachers $\mathrm{N}_{2}=$ number of technical inexperienced, $\mathrm{N}=$ total number of the respondents

Research question 1 set out to identify the ICT Skills possessed by technical Teachers for Instruction in Technical Colleges in Kano State. Nineteen (19) items are presented to the respondent. The results indicate that all the 19 items presented received mean responses between 2.20 to 4.05 showing that, the two group of respondent agreed that technical teachers almost possessed skills on some items and do not possessed skills on other items. The two groups of respondents have a standard deviation range of 0.99 to 1.38 and this indicates that, the electrical installation and maintenance teachers are skillful in some of the items and are unskillful in some of the items in the research question. The grand mean of the two groups shows a mean of 3.35. Based on the data presented and the subsequent analysis, the researcher concludes that, the entire respondent considered the ICT Skills possessed by technical Teachers for Instruction in Technical Colleges in Kano State as unskilful. The findings from the results presented showed that technical teachers are unskillful. This is in agreement with the findings of Duhu, Mbaga, Quahha, and Danzaria, (2014) which revealed 
that electrical engineering trade teachers lack some basic ICT skills such as database and spreadsheet utilization. Duhu, Mbaga, Quahha, and Danzaria further stated that electrical engineering trade teachers perceived themselves as having inadequate skills required to use the ICT for classroom instructions. In further support of the findings, Deebom and Goma (2018) reported that the need for an effective way to achieve sustainable development is the integration of technology in all spheres of education, however, the manpower needs is lacking as there is deficit in knowledge possessed by the workers especially the teachers.

\section{Level of ICT Utilization by Technical Teachers in Technical Colleges of Kano State}

Table 2: Mean Rating and Standard Deviation of Opinion of the Level of ICT Utilization

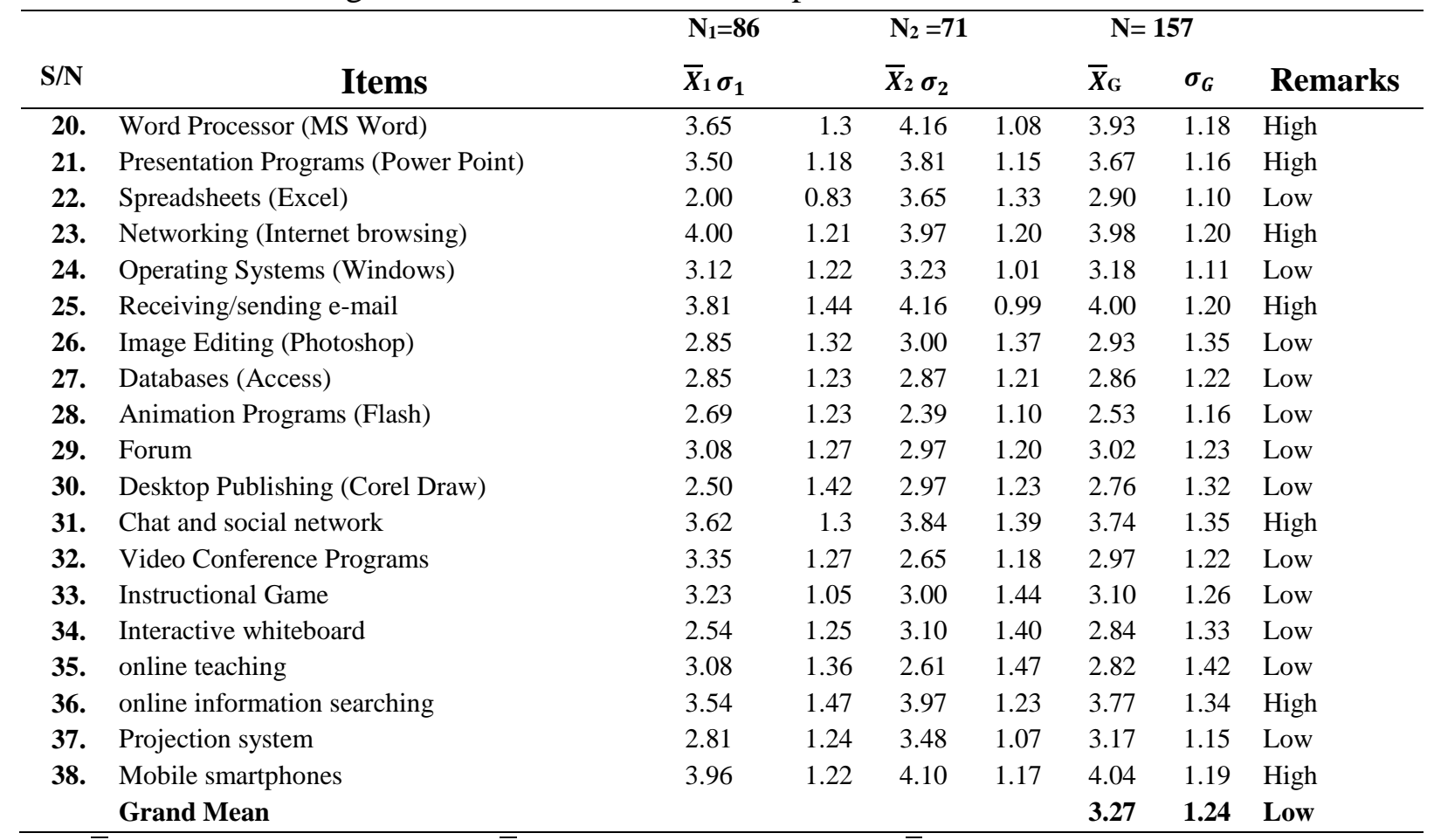

Key: $\overline{\boldsymbol{X}}_{1}=$ mean response of technical teachers, $\overline{\boldsymbol{X}}_{2}=$ mean response of technical students $\bar{X}_{\mathrm{G}}=$ Grand of items, $\sigma=$ standard deviation, $\mathrm{N}_{1}=$ number of technical teachers $\mathrm{N}_{2}=$ number of technical students, $\mathrm{N}=$ total number of the respondents

Research question 2 set out to identify the level of ICT utilization by technical teachers in technical colleges in Kano State. Nineteen (19) items are presented to the respondent. The results indicate that all the 19 items presented received a range of mean responses from 2.53 to 4.04 showing that, the two group of respondent indicated that the ICT utilization in some items is low and is high in other items. The standard deviation also shows that, the two groups of respondents have a range of 1.10 to 1.42 and this indicates that, the respondent consider ICT utilization on some items is high and consider ICT utilization on other items is low in the research question. The grand mean of the two groups shows a mean of 3.27. Based on data presented on this research question, the researcher concludes that, the entire respondent considered the level of ICT utilization by technical teachers in technical colleges in Kano State as low.

The responses to the items as presented in table 3 indicated that 12 out of 19 items presented have low utilization. This is in conformity with the findings of Daniel (2014) who found out 
that the extent of utilization of ICTs in teaching business education is not encouraging which posed challenges for effective teaching/learning of business education. It is also in agreement with the findings of Chijioke (2013) which found that that teachers were aware of ICT resources but do not utilize them while teaching. The findings also agree with the findings of Sango and Aliyu (2018) which revealed that teachers don't utilize ICT facilities due to lack of skills and lack of adequate training.

Significance Difference between the Mean Responses of Experienced and Inexperienced Teachers on ICT Skills Possessed by Technical Teachers in Technical Colleges of Kano State

Table 3: Z-Test Analysis of Difference between Opinions of the Two Group of Respondents

\begin{tabular}{lcccccc}
\hline Respondents & $\mathbf{N}$ & $\overline{\boldsymbol{X}}$ & $\mathbf{S}^{\mathbf{2}}$ & Z-calc & Z-crit & Decision \\
\hline Experienced Teachers & 86 & 3.41 & 0.22 & & & \\
Inexperienced Teachers & 71 & 3.43 & 0.28 & & & Reject \\
\hline
\end{tabular}

Key: $\mathrm{N}=$ number of respondents, $\bar{X}=$ mean of the group of respondents, $\mathrm{S}^{2}=$ standard deviation of each group, z-cal= calculated z-value, $\mathrm{z}$ crit $=z$-table value

Table 3 revealed the opinion of technical teachers and students on the ICT skills possessed by technical teachers was tested statistically with a z-test at 0.05 level of significance. The data showed that z-cal (-0.41) was less than the z-crit (1.96) at 0.05 level of significance. Therefore, the null hypothesis was rejected indicating that, there is significant difference between the mean responses of technical teachers and students on the ICT skills possessed by technical teachers in technical colleges in Kano state. Based on the data presented on the table 3 above, the finding has shown that, both technical experienced teachers and inexperienced teachers have similar opinion on the ICT skills possessed by technical teachers hence the null hypothesis was rejected.

This is most likely due to the fact that technical experienced and inexperienced teachers have different view on the ICT skills possessed by technical teachers. The finding is in line with Matthew, Joro and Manasseh (2015) who reported that there is always a divergent view between experts and novice on the basic skill needed by in any occupation as the novice is ignorant of the basic requirement of the occupation. Therefore, it is not surprising for existence of the statistical difference in the opinions of the experience and inexperience teachers on the ICT skills possessed by technical teachers.

Significance Difference between the Mean Responses of Experienced and Inexperienced Teachers on the Level of ICT Utilization by Technical Teachers in Technical Colleges of Kano State

Table 4: Z-Test Analysis of Difference between Opinions of the groups of the respondents

\begin{tabular}{lcccccc}
\hline Respondents & $\mathbf{N}$ & $\overline{\boldsymbol{X}}$ & $\mathbf{S}^{\mathbf{2}}$ & $\mathbf{z}$ - calc & z- crit & Decision \\
\hline Experienced Teachers & 86 & 3.32 & 0.24 & & & \\
& & & & -0.54 & 1.96 & Not significant
\end{tabular}


Table 4 revealed that $\mathrm{z}$-cal $(-0.54)$ was less than the $\mathrm{z}$-crit (1.96) at 0.05 level of significance. Therefore, the null hypothesis was rejected indicating that, there was significant difference between the mean responses of technical experienced and inexperienced teachers on the level of ICT utilization by technical teachers in technical colleges in Kano state. The finding on the Table 4 showed that the opinion of technical teachers on the level of ICT utilization by technical experienced teachers was in variance with the opinion of the inexperienced teachers. This implies that both the technical experienced and inexperienced teachers have divergent views on the level of ICT utilization by technical teachers in technical colleges in Kano state hence the null hypothesis was rejected. This was corroborated by Allan and Trani (2018) who found out that there was statistically significant different on the extent to which teacher utilization of ICT affect the performance of their teaching, assessment and administration. The finding was also supported by Musa and Kanya (2014) who reported that though the essence of ICT is enormous, people will always have different views about it.

\section{Conclusion and Suggestion}

Based on the findings of this study, it was concluded that, technical teachers possessed skill in the following; MS word, power point, internet, operating system, sending/receiving email, chat and social network, online information searching, projection system and mobile smartphone. Which are basic skills one would possess in order to be able to operate a computer. The technical teachers were unskilful in the following; MS excel, Photoshop, database, animation, forum and Corel draw, video conferencing, instructional game, interactive whiteboard and online teaching as the utilization of ICT facilities was low among technical teachers in Technical Colleges of Kano State.

Based on the findings of the study, the following suggestions were made:

1. Government should provide ICT infrastructure in the state's Technical colleges in order to have a conducive environment for teaching of the trade subjects and enforce integration by regular supervision.

2. The school management should encourage adequate utilization of ICT facilities by Technical Teachers by ensuring proper supervision and rewarding teachers who comply.

\section{Acknowledgments}

The authors wish to acknowledge with thanks the immeasurable contribution of Dr. D. Moses for always being available and giving guidance to the accomplishment of this project work. Profound thanks goes to Prof. I. Tumba and Dr. Kumazhege, S. Z. for finding time to read the manuscript of the work at content and design stages respectively. 


\section{Conflict of Interest}

The authors declare no conflict of interest.

\section{Funding}

All associated financial burden for conducting the study and for publishing this article is the responsibility of the authors

\section{References}

Adeosun, O. (2010). Quality basic education development in Nigeria: Imperative for use of ICT. Journal of International Cooperation in Education, 13(2), 193-211.

Akintude, S. A. (2014). Libraries as tool for ICT development. A paper presented at the 2004 NLA National Conference and AGM, held at Akure 20-25 June, 2014. p10.

Allan B. A and Trani L. C. (2018), Extent of utilization of information and communication technology (ICT) by selected secondary school teachers of city schools division of malolos: basis for the development of strategic action plan International Journal of Education and Research, 6(1), 35-47

Anyim, W. O. (2018). Assessment of ICT literacy skills of digital library users and staff in Salem University Lokoja. Kogi. Library Philosophy and Practice (e-journal), 1-24

Basil, C. E. et al, (2020). Assessment of ICT skills relevant for effective learning possessed by undergraduate students at University of Nigeria. International Journal of Higher Education, 9(4), 206 - 216

Chijioke, A. I. (2013). Computer technology in nigerian secondary school education: problems and prospects. Journal of Resourcefulness and Distinction, 6(1) 102-117

Daniel, J. A. U. (2014), Extent of Utilization of Information and Communication Technology in Business Education: Implication for Effective Instructional Delivery Educational Research International, 3(4), 16-22

Deebom, M. T. \& Goma, O. T. (2018), Utilization of Information Communication and Technology for Sustainable Manpower Development among Technical Educators in Tertiary Institutions in Rivers State, Nigeria. International Journal of Innovative Information Systems \& Technology Research 6(2):48-58

Duhu, P. C., Mbaga, E. V., Quahha, D. W, \& Danzaria, L.(2014). The Perception of electrical engineering trade teachers on the use of information and communication technology for teaching in technical colleges in Adamawa and Gombe states of Nigeria. European Scientific Journal, 10(13), 12-21

Etuk, G. K. (2016). Education financing for college and University. Uyo: Abam Publication Co.

Haywood, D. (2013). Confidence, experience and attitudes of undergraduate students towards CT. Survey of European Universities Skills in ICT of Students and Staff (SEUSISS).

URL: http://www.elearningeuropa.info/index.php?page=doc\&doc_id=4097\&doclng=1 
Kumazhege, S. Z. \& Ogunsola, A. O. E (2014). technical teachers' perception of factors affecting practical skills acquisition among technical college graduates in Adamawa State Nigeria. Educational Research International, 3(3), 95-101

Mohammed, K. \& Yarinchi, B. M. (2013) Information communication technology (ICT) and media education: In Historical Perspective. European Scientific Journal 9(20), 111-23

National Board for Technical Education (NBTE) (2007). National Technical Certificate Examination (craft level) Syllabus for Engineering Trades based on the NBTE modular curricular. Kaduna: NBTE Press

Nikitakis, M. (2017). Proceedings of the $16^{\text {th }}$ Panhellenic Conference or Academic Libraries, Pireas, Greece. 1-3. 532-544.

Odede, I. \& Enakerakpo, E. (2014). ICT skills and internet usage among Library and Information Science students in Delta and Edo States, Nigeria. Internaltional Journal of Librry and Information Scinece, 6(5), 98-107. https://doi.org/10.5897/IJLIS2013.0360

Okoye, K. R. E. \& Okwelle, P. C. (2017). New perspectives on technical and vocational education and training in Nigeria. Journal of Education, Society and Behavioural Science, 23(4), 1-9

Olurinola, O. D. (2016). Effect of presentation media on students learning outcomes in visual arts. Nigerian Journal of Educational Technology, 1(2), 69-77.

Rastogi, A. \& Malhotra, S. (2013) ICT skills and attitude as determinants of ICT pedagogy integration; European Academic Research, 1(3), 222-231

Saddiquah, A. \& Salim, Z. (2017). The ICT facilities, skills, usage, and the problems faced by the students of higher education. EURASIA Journal of Mathematics Science and Technology Education, 13(8), 4987-4994. http://dx.doi.org/10.12973/eurasia.2017.00977a

Saidu, S. G \& Ajuji, J. K. (2017). Technical and vocational education and training and entrepreneurship education for job creation and national development in Nigeria. Journal of Association of Vocational and Technical Development in Nigeria, 21(2), 227-233

Sango, A. \& Aliyu, M. (2015). Challenges militating against the utilization of information and communication technology by nigerian teacher educators for sustainable development International Policy Brief Series Social Science and Law Journal of Policy Review and Development Strategies, 4 (1), 34-40.

(2018). Challenges militating against the utilization of information and communication technology by Nigerian teacher educators for sustainable development International Policy Brief Series Social Science and Law Journal of Policy Review and Development Strategies, 4(1), 124-130

UNESCO (2015). Current issues and trends in technical and vocational education. Section for technical and vocational education UNESC0, Paris: A. Dyankov

UNESCO, (2017). ICT in Education. United Nation Educational Scientific and cultural Oranization: ParisUNN Statistic Unit (2020). University of Nigeria Statistics. University of Nigeria Nsukka (UNN). 